arranged that it is scarcely worth while to particularise them. Of course the battery current thus liberated by the excited current could be used for controlling other clocks.

The effect on the pendulum is thus restricted to the quicker parts of its swing ; and consists of slightly retarding the descent, and accelerating the ascent, apart from all mechanical friction or contacts. Thus each action is produced at the most suitable time.

Possibly a pendulum cutting off heat rays from a thermopile might thus work a switch, and be even less affected than by producing an excited current in the coil-bob, as proposed above. Bromley, Kent W. M. Flinders PETrie

\section{Did Flowers Exist during the Carboniferous Epoch?}

NoTICING in your pages under the above heading a discussion on fossil butterfiles and moths, \&c., and being struck with the deep interest taken in the question as evidenced by the letter of the Rev. A. E. Eaton (vol, xx. p. 3I5), I thought that I would ask for a very small space for an intercommunication which may forward investigation.

I have in my collection what appears to me to be a butterfly (using the word without any regard to scientific nomenclature), as a carbonaceous impress on a piece of shale from the Slievardagh coal-field, Tipperary; and by way of contributing my mite towards an inquiry which it gives me pleasure to find so earnestly pursued, I shall be happy to forward the specimen for examination to any of the scientific gentlemen interested who will furnish me his address, or in turn to as many as it will be convenient so to accommodate, on condition that the specimen be return: do me in good order and without unreasonable delay.

I may be allowed to add that I have no sympathy whatever with the discussion in its present bearings.

Earlshill Colliery, Thurles, August 7

WILLIAM MORRIS

\section{"Euclid and His Modern Rivals"}

MR. DODGSON thinks "it worth while to point out a mistake made in the paragraph about Mr. Morell's book" (NATURE, vol. $\mathrm{xx} . \mathrm{p} .240)$. In the words " the thing not being capable of proof," the "thing" referred to is Mr. Morell's assertion that "the perimeter MDQRSTM is less than the perimeter MPQRSTM," which is not necessarily true, and of course is incapable of proof. Surely this assertion, which I quote two lines before "thing" occurs, is its grammatical antecedent? You refer it back to the theorem itself, which Mr. Morell is trying to prove-a theorem which is true and easily proved." I gladly accept Mr. Dodgson's statement, which is, if I remember rightly-for I am here far away from Mr. Dodgson's bookperfectly correct-and apologise for having inaccurately represented his meaning.

THE WRITER OF THE NOTICE OF "EUCLID AND His MODERN Rivals"

Penzance, August 8

\section{SOCIETIES AND ACADEMIES LONDON}

Entomological Society, August 6.-J. W. Dunning, M.A., F.L.S., vice-president, in the chair.-Mr. Philips exhibited living specimens (both sexes) of Spercheus emarginatus, taken at West Han,-Mr. Stainton exhibited, on behalf of Mr. Grigg, of Bristol, larvæe of Rösterstammia erxIebella, a genus of which the larva had hitherto been unknown.-Miss Ormerod read a paper entitled "Sugar-cane Borers of British Guiana," and exhibited specimens of the insects referred to, in different stages of development. The exhibition was made on behalf of the Colonial Company, who were anxious to receive any information as to available and practical methods of dealing with these in sects. Mr. Distant stated that the circumstances were almost the same on the sugar estates in the Straits Settlements at Malacca, where burning the infected canes was the usual remedy applied. - Mr. Swinton communicated a note with reference to the urti. cating properties of the larva of Liparis aurifua, and a communication was also received from Mr. McLachlan on correlation of mutilation in the larva with deformity in the imago, being the substance of a notice by M. Melise on the subject in the Compte Rendu of the Belgian Entomological Society.

\section{VIENNA}

Imperial Academy of Sciences, June r3.-On two new Notodelphyides, with remarks on some features in the organisation of this family, by Herr Kerschner.-On the yearly reriod of the insect fauna of Austria-Hungary, No. IV., by Herr Fritsch. -On the motion of plates between the electrodes of a Holtz machine, by Herr Doubrava.-On the perfect pentagon, by Herr Kohn.-On the specific viscosity of a liquid and its relation to chemical constitution, by Prof. Pribram and Dr. Handl.-On the crystalline form and optical properties of isodulcite, by Prof. Urba.-Determination of the inclination from oscillation of a magnetic bar, by Prof. Pscheidl.-The Ferdinandsbrunn spring at Marienbad in Bohemia, by Prof. Gintl.

\section{PARIS}

Academy of Sciences, August II.-M. Daubrée in the chair.-Experimental researches on the erosive action of highiy compressed and highly heated gases, and their application to the history of meteors and bolides, by M. Daubrée.-On the acids generated when the crude acids resulting from the saponification of neutral fats are distilled in a currenti of super-heated steam, by MM. A. Cahours and Demarçay.-Reply to M. Berthelot's note on hydrate of chloral, by $M$. Wurtz. - On the generation of electricity by the Rays, by M. Ch. Robin.-On the eclipse of July Ig last, observed at Marseilles, by M.J. Janssen. - Second and last observation by M. A. Ledieu, on M. Bouquet de la Grye's paper on atmospheric waves.-M. Palacciano was elected correspondent in the Medical and Surgical Section of the Academy, in place of the late M. Lebert.-On some properties of quadratic forms, by M. Poincaré,-On hydro. dynamical principles and the application of these principles, by $M$. G. Clère. - On the formation of nitric ether in wine, by $M$. Romanet du Caillaud.-On the distillation of liquids under the influence of static electricity, by M. D. Gernez.-On Ampère's currents, by M. Trève.-On the vapour densities of some organic substances with high boiling points, by M. L. Troost.-On the density of chlorine at high temperatures, by M. Ad. Lieben.-On the synthesis of phenol glucoside, and of ortho-formylglucoside or helicine, by M. A. Michael.-On a combination of chromic acid with fluoride of potassium, by M. L. Varenne.-On the production of crystallised metallic oxides by means of cyanide of potassium, by the same.-On the identity of hydrate of diisoprene and of caoutchine with terpene.-On the conservation of green fodder, by M. G. Lechartier.-On the latent irritation of the muscle in frogs and in man, both in the healthy and the diseased states, by M. M. Mendelssohn.-On the electric irritation of the apex of the heart, by MM. Dastre and Morat.-On the action of the poison from Bethrops jarara. cussu, by MM. Couty and de Lacerda. - Causes of the alteration of animal temperature produced by ether, chloral and chloroform, by M. Arloing.- On the structure of the cephalic ganglions of insects, by $M$. W. Wagner.-On the rot of the vine, by $M$. A. Millardet.-On the temperature of the month of July, I879, by M. E. Renou.-On the history of perfect numbers, by M. L. Hugo.

\section{CONTENTS}

Weather Charts for the Northern Hemisphere . . . . . 38 i

The British Assoctation. . . . . . . . . . . . . . . 38

Inaugural Address of Prof. G. J. Allman, M.D., LL.D., F.R.S.S.I.

and E., M.R.I.A., Pres. L.S., President . . . . . . . 384

Section D-Biology-Opening Address by Prof. St. George Mivart,

F.R.S., Sec. L.S., V.P.Z.S., President of the Section . . . . 393

NOTES.................. . . 400

Our Astronomical Column:-

The Elongated Nebulec . . . . . . . . . . . 402

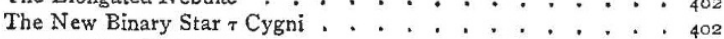

LETTERS TO THE EDITOR:-

"Report of an Unusual Phcacmenon Observed at Sea."-EDWARD H. PRINGLE (With Dingrams) . . . . . . . . . . 402

The Planet Jupiter.-John BiRminghaM . . . . . . . . . 403

Twenty-nine Gleams of Sun hine, August 7, 8, 9, in Nine Hours.J. F. CAMPBell (With Diagram). . . . . . . . . . . 403

Electric Clocks.-W. W. Flinders Petrie . . . . . . . . : 404

Did Flowers Exist during the Carboniferous Epoch?-WiLliam

Morris . . . . . . . . . . . . . . . . . 404

"Euclid and His Modern Rivals."-The Writer of the Notice

of "EUClid and His Modern Rivals" . . . . . . 404 Socteties and ACademirs . . . . . . . . . . . . . . . . . 404 